\title{
PENGEMBANGAN DRUG DISCOVERYDARI BAHAN ALAMI LAUT UNTUK IMUNOTERAPI KANKER
}

\author{
Ariyanti Suhita Dewi ${ }^{*}$
}

\begin{abstract}
ABSTRAK
Penyakit kanker adalah permasalahan kesehatan global yang mengancam setiap individu baik di negara maju maupun di negara berkembang. Penanganan kanker sejauh ini dilakukan berdasarkan metode konvensional yang cenderung menurunkan kualitas hidup para penderitanya. Pendekatan imunoterapi kanker adalah suatu metode pengobatan kanker dengan cara menstimulasi sistem kekebalan hidup pasien untuk melawan tumor melalui regulasi enzimenzim yang berperan penting pada jalur molekuler tertentu dengan tujuan untuk meminimalisasi terjadinya efek samping yang tidak diinginkan yang umumnya terjadi pada terapi konvensional. Beberapa target molekuler telah dikembangkan saat ini, diantaranya adalah penghambatan enzim Indoleamine-2,3-dioxygenase (IDO) dan pengaktifan enzim SHIP (SH2-containinginositol-5-phosphatase). Senyawa-senyawa bioaktif dari bahan alam laut yang telah dilaporkan sebagai regulator kedua enzim di atas akan dijabarkan.
\end{abstract}

\section{ABSTRACT: The development of drug discovery from marine natural products for cancer immunotherapy. By: Ariyanti Suhita Dewi}

Cancer disease is a global health issue that threatens the life of any individual in both developed and developing countries. The treatment of cancer nowadays is performed based on the conventional therapies that tend to decrease the life quality of patients with cancer. Cancer immunotherapy is a method that treats cancer by stimulating the patient's immune system to work against tumor by regulating enzymes in certain molecular pathways and therefore minimize the unwanted side effects that normally occur due to the conventional therapies. Several molecular targets have been developed recently, including the inhibition of Indoleamine-2,3-dioxygenase (IDO) and the activation of SH2-containing-inositol-5-phosphatase (SHIP). Bioactive compounds that have been reported as the regulators of both enzymes will be presented.

\section{KEYWORDS: $\quad$ marine natural products, cancer immunotherapy, IDO, SHIP}

\section{PENDAHULUAN}

Penyakit kanker adalah permasalahan kesehatan global yang mengancam setiap individu baik di negara maju maupun negara berkembang. Penyakit kanker ditandai dengan adanya pertumbuhan sel yang tidak terkendali akibat pengaruh eksternal (zat-zat karsinogen, virus, dan radiasi) dan internal (mutasi gen, hormon, dan kekebalan tubuh yang lemah) (American Cancer Society, 2008; Boik, 1995). Pervaiz (2002) menambahkan bahwa kanker memiliki kemampuan untuk bereplikasi tidak terbatas, mempunyai ketercukupan sinyal pertumbuhan, tidak sensitif terhadap sinyal anti-pertumbuhan, kemampuan berangiogenesis (membentuk pembuluh darah), bermetastasis (menginvasi jaringan), dan menghindari apoptosis (bunuh diri sel secara sistematis).

Data statistik di Amerika Serikat (AS) menunjukkan bahwa sekitar $77 \%$ individu yang didiagnosa menderita kanker adalah individu berusia lebih dari 55 tahun. Dilaporkan pula bahwa satu dari empat kematian di
AS disebabkan oleh kanker. Fenomena ini menempatkan kanker sebagai penyakit mematikan kedua setelah penyakit jantung. Lebih lanjut ditunjukkan bahwa 1,4 juta orang di AS terjangkit penyakit kanker pada tahun 2008 dan sebanyak 560.000 orang diantaranya meninggal dunia, yang berarti sekitar 1500 orang meninggal setiap harinya akibat kanker (American Cancer Society, 2008). Suatu angka yang sangat fantastis. Hingga tahun 2007, jenis kanker yang dianggap paling mematikan adalah kanker paru-paru dan bronkus. Sementara timbulnya insiden kasus kanker baru pada laki-laki adalah kanker prostat dan kanker payudara untuk perempuan (Jemal et al., 2007).

Pengobatan kanker yang umum dilakukan saat ini adalah melalui operasi, radiasi, dan kemoterapi (pengobatan secara kimiawi). Meskipun dalam beberapa kasus efektif dalam mengeliminasi kanker, kemoterapi juga berdampak pada penurunan kualitas hidup pasien selama dan pasca proses pengobatan karena efek toksisitas senyawa yang terkandung di dalamnya. Meskipun riset penelitian obat kanker

\footnotetext{
*) Peneliti pada Balai Besar Riset Pengolahan Produk dan Bioteknologi Kelautan dan Perikanan
} 
dewasa ini telah banyak difokuskan untuk memperoleh senyawa obat yang memiliki selektivitas tinggi terhadap sel kanker dan kerusakan minimum terhadap sel normal, akan tetapi hampir semua senyawa obat yang dikembangkan saat ini tidak memenuhi tingkat selektivitas tersebut. Selain itu, sel kanker bersifat sangat adaptif dan memiliki kemungkinan untuk membentuk resistensi apabila suatu obat tunggal dipergunakan selama periode waktu tertentu. Oleh karena itu, mendesain suatu terapi yang secara langsung menyerang target alur molekuler sel kanker adalah suatu metode yang dirasa paling rasional dan logis untuk menghambat pembentukan dan pertumbuhan kanker (Pervaiz, 2002).

\section{IMUNOTERAPI KANKER SEBAGAI PENDEKATAN BARU DALAM PENGOBATAN KANKER}

Riset mengenai imunoterapi kanker dimulai pada tahun 1890 oleh William Coley yang berprofesi sebagai dokter bedah berkebangsaan Amerika Serikat, yang mengamati bahwa infeksi pada pasien kanker selalu disertai dengan pengurangan sel kanker. Coley kemudian mengembangkan suatu toksin yang diperolehnya dari Streptomyces pyogenes untuk mengobati pasien kanker. Penemuannya ini diterbitkan pada tahun 1893 yang didalamnya menerangkan konsep imunoterapi kanker. Selama 110 tahun berikutnya, terdapat setidaknya lima fluktuasi dramatis mengenai konsep ini, hingga pada akhirnya riset-riset terbaru membuktikan bahwa respons imun manusia dapat mengenali dan mengeliminasi tumor (Parish, 2003).

Sistem kekebalan tubuh manusia memiliki kemampuan yang mengagumkan apabila dipergunakan secara optimal. Pendekatan imunoterapi untuk mengatasi kanker adalah suatu terobosan baru dalam dunia kesehatan. Berbeda dengan konsep terapi konvensional, imunoterapi kanker adalah suatu metode pengobatan yang bertujuan untuk menghambat metastatis kanker dan meningkatkan kualitas hidup pasien penderita kanker (Schuster et al., 2006).

Tubuh manusia pada dasarnya dilengkapi dengan suatu sistem pemantau kekebalan. Sel-sel imun bersifat peka terhadap adanya sinyal "bahaya" yang ditimbulkan oleh sel kanker akibat adanya stres genotoksik pada transformasi sel dan gangguan lingkungan di sekitar sel normal. Pada kondisi ideal, sinyal ini akan menginisiasi terjadinya inflamasi, mengaktifkan sel efektor yang memiliki aktivitas antitumor dan merangsang sel-sel antigen (antigen-presenting cells, $A P C$ ), terutama sel dendritis (dendritic cells, $D C$ ), untuk menghambat sel antigen tumor dan bermigrasi ke simpul pembuangan limfosit tumor untuk memicu respon adaptif dari limfosit T dan B (Blattman et al., 2004).

Suatu model terintegrasi antara onkogenesis dan immunoediting ini akan menjabarkan konsep yang lebih mendalam tentang "pertarungan seri" antara tumor dan sistem imun yang mengakibatkan dormansi tumor di mana tumor dapat bertahan secara dinamis dalam jangka waktu yang lama (Gambar 1). Pada kondisi ideal, sel normal yang tertransformasi akan dieliminasi oleh sistem imun. Pada saat kesetimbangan, sel yang tertransformasi akan membentuk dormansi tumor, sedangkan sel yang lolos dari pengawasan sistem imun bermetastasis menjadi kanker. Inilah saat-saat kritis dimana upaya memperkuat sistem kekebalan sangat krusial karena adanya aktivitas melemahnya sistem imum dapat mengakibatkan terjadinya invasi dan metastasis kanker (Prendergast, 2008).

Penelitian mengenai target molekuler untuk pengobatan kanker telah banyak dikembangkan dewasa ini. Diantaranya adalah pengembangan riset tentang Indoleamine-2,3-dioxygenase (IDO) dan SH2 containing inositol-5-phosphatase (SHIP) sebagai target pengobatan kanker yang akan dijabarkan berikut ini.

\section{INDOLEAMINE-2,3-DIOXYGENASE (IDO)}

\section{Ekspresi IDO pada sel kanker}

Pada tahun 1950, suatu fenomena peningkatan kadar triptofan pada penderita kanker kandung kemih pertama kali dikenali. Fenomena yang sama ternyata juga ditemui pada penderita kanker payudara, prostat, Hodgkyn's lymphoma, dan leukemia (Katz et al., 2008). Telah lama diketahui bahwa sel-sel limfosit pada mamalia sangat sensitif pada ketersediaan dan konsentrasi beberapa asam amino tertentu di sekitarnya. Akibatnya, degradasi atau penurunan kadar asam amino tersebut dapat menyebabkan perubahan fungsi imun (Zamanakou et al., 2007). Munn \& Mellor pada akhir tahun 1990, mengkonfirmasi hubungan antara penurunan kadar triptofan dan fungsi imun ini. Mereka melaporkan adanya aktivitas IDO yang mencegah penolakan fetus allogeneic (berbeda secara genetis) yang umumnya terjadi pada tikus normal akibat imunitas maternal sel T (sel limfosit dari timus) (Katz et al., 2008).

Beberapa riset terbaru menunjukkan adanya ekspresi IDO pada sel kanker yang dideteksi pada zona infiltrasi tumor, peritumoral stroma, simpul pembuangan limfosit tumor. Lebih lanjut dijelaskan bahwa ekspresi IDO turut bertanggungjawab untuk memicu lolosnya tumor dari pengawasan sistem imun. 


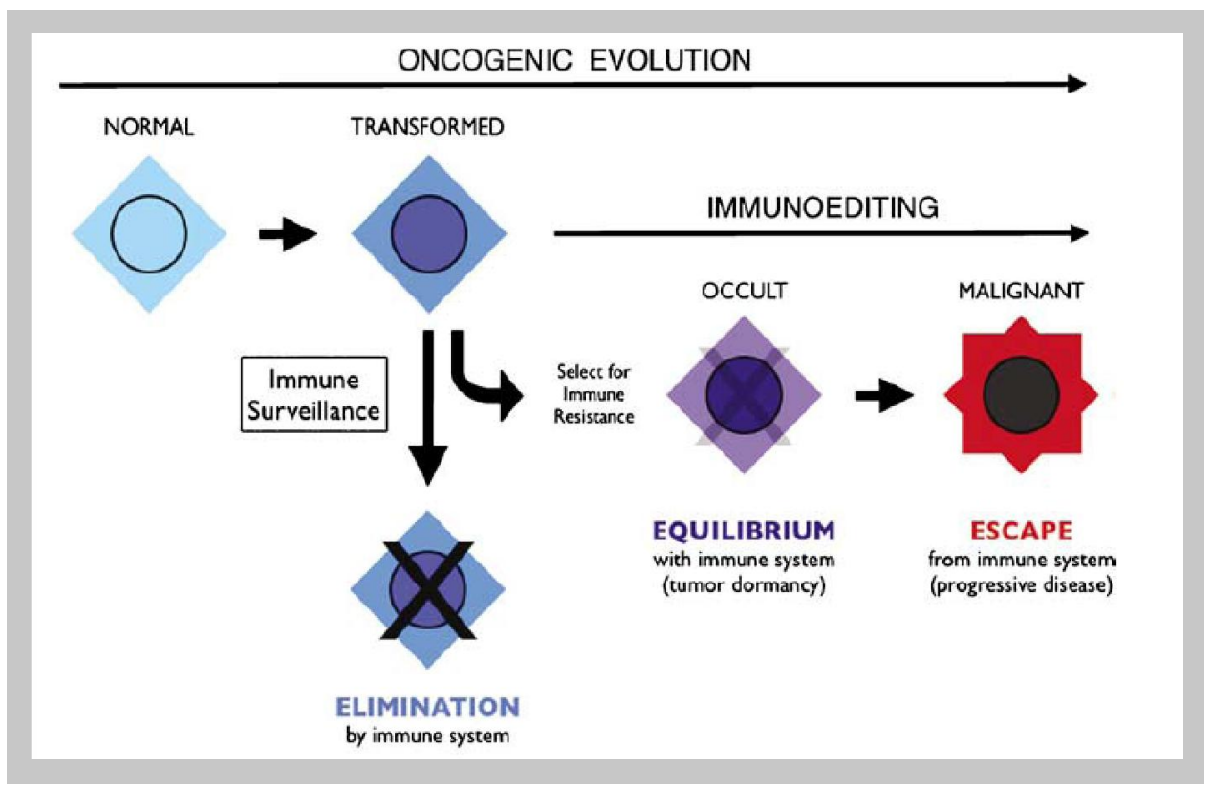

Gambar 1. Proses immunoediting (Prendergast, 2008).

Sebagai hasilnya, kini ekspresi IDO dijadikan sebagai penanda klinopatologi dengan hasil prognosis yang signifikan (Zamanakou et al., 2007).

\section{IDO memicu lolosnya tumor dari pengawasan sistem imun}

IDO adalah suatu monomer hemoprotein yang terdapat di dalam sitoplasma. IDO terdiri atas 403 asam amino dengan berat molekul 45.324 Dalton dan bertugas untuk mengkatalisis katabolisme triptofan melalui jalur kinurenin (Zamanakou et al., 2007). Pada tahun 1963, IDO dikenal sebagai $D$-triptofan pirolase yang diekspresikan secara tersebar dengan kadar yang tinggi pada paru-paru, perut, epididimis dan timus (Mellor et al., 2005). Studi kristalografi pada IDO manusia menunjukkan bahwa IDO terdiri atas dua struktur domain dari domain $\alpha$-heliks dengan sebuah grup heme (suatu bagian prostetik dalam hemoglobin yang mengandung zat besi) di pusatnya. Aktivitas IDO sangat tergantung pada heme tersebut dan donor elektron. Bagian heme pada IDO menyediakan anion superoksida yang mendonasikan oksigen pada triptofan (Katz et al., 2008).

Mekanisme penghambatan fungsi imun oleh IDO ditunjukkan pada Gambar 2. IDO mengkatalisis degradasi triptofan melalui jalur kinurenin. Asam

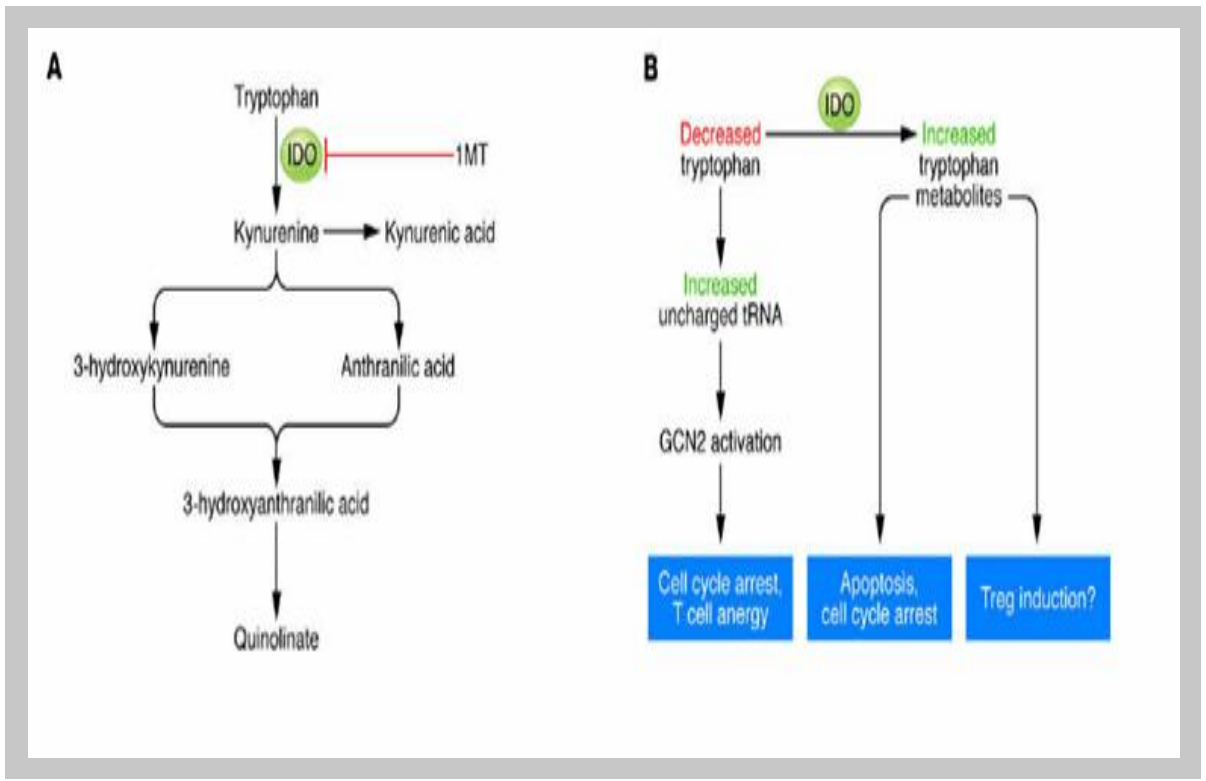

Gambar 2. Mekanisme penghambatan fungsi imun oleh IDO (Munn et al., 2006). 
amino triptofan diketahui memiliki aktivitas immunomodulator, oleh karena itu katabolisme triptofan berakibat pada berkurangnya fungsi imun. 1-MT (1-metil triptofan) adalah senyawa obat yang saat ini dikembangkan untuk menghambat aktivitas IDO (Gambar 2A). Lebih lanjut dijelaskan pada Gambar 2B bahwa jumlah triptofan yang menurun menyebabkan meningkatnya tRNA yang tidak bermuatan dan aktivasi GCN2, yang pada akhirnya mengakibatkan berhentinya siklus sel dan penurunan fungsi sel $\mathrm{T}$ (sel imun). Sebaliknya, peningkatan metabolit triptofan dapat menyebabkan berhentinya siklus sel kanker, apoptosis dan diduga juga dapat menginduksi diferensiasi Treg dari CD4 ${ }^{+}$sel T (Munn et al., 2006).

Sebagai target pengembangan obat kanker, IDO memiliki beberapa kelebihan. Pertama, IDO mudah dikontrol untuk pengembangan senyawa inhibitor IDO dibandingkan target kanker terapi yang lain. Kedua, IDO memiliki spesifikasi substrat yang lebih luas dibandingkan enzim lain dengan aktivitas yang sama. Ketiga, senyawa-senyawa inhibitor IDO yang tersedia dapat digunakan sebagai bahan untuk studi preklinis. Keempat, senyawa-senyawa tersebut sejauh ini mempunyai toksisitas yang terkontrol. Kelima, evaluasi farmakodinamis dari senyawa inhibitor IDO dapat dilakukan dengan mudah dengan cara menentukan level triptofan (substrat IDO) dan kinurenin (produk IDO) pada serum darah. Terakhir, pengembangan senyawa inhibitor IDO membutuhkan biaya yang lebih murah dibandingkan terapi berbasis sel dan biologi yang bertujuan untuk memodulasi imunitas (Muller et al., 2005).

Grup Andersen pada tahun 2006 melaporkan senyawa berbasis cincin naftokuinon yaitu Annulin B
(Ki 0,12 $\mu \mathrm{M}, 1$ ) yang memiliki kemampuan menghambat IDO dengan potensi nanomolar. Senyawa ini diisolasi dari hidroid laut Garveia annulata dari perairan timur laut Pasifik. Di samping itu, grup Andersen juga menemukan senyawa penghambat IDO paling fenomenal yaitu Exiguamine $\mathrm{A}(K \mathrm{i} 0,04 \mu \mathrm{M}, 2)$, suatu senyawa yang mengandung gugusan hidantoin dan kuinon hasil isolasi dari spons laut Papua Nugini Neopetrosia exigua dan merupakan senyawa penghambat IDO paling aktif hingga saat ini. Lebih lanjut Dewi (2009) melaporkan bahwa senyawa Isoaaptamin $\left(\mathrm{IC}_{50} 8,8 \mu \mathrm{M}, 3\right)$ dari spons laut Aaptos cf. suberitoides menambah khasanah senyawa-senyawa penghambat IDO dari biota laut.

\section{SH2 CONTAINING INOSITOL-5-PHOSPHATASE (SHIP)}

\section{SHIP menghambat jalur phosphatidyl-inositol- 3'-kinase (PI3K)}

PI3K adalah suatu komponen penting yang berfungsi sebagai sinyal pertumbuhan sel. Fosfoinositida, terutama phosphatidylinositol-3,4,5triphosphate ( $P I-3,4,5-P 3)$ adalah senyawa turunan yang dihasilkan dari jalur PI3K yang terlibat dalam regulasi fungsi sel, seperti proliferasi, diferensiasi, apoptosis, aktivasi sel, pergerakan sel dan adesi. Sebagai akibatnya, deregulasi jalur PI3K sangat penting untuk pertumbuhan kanker dan oleh karenanya, penghambatan komponen-komponen pada jalur ini telah banyak digunakan sebagai target penemuan dan pengembangan obat anti kanker (Prasad et al., 2008).

Pada tahun 1997, tiga grup peneliti secara terpisah memurnikan dan mengklon suatu protein dengan berat

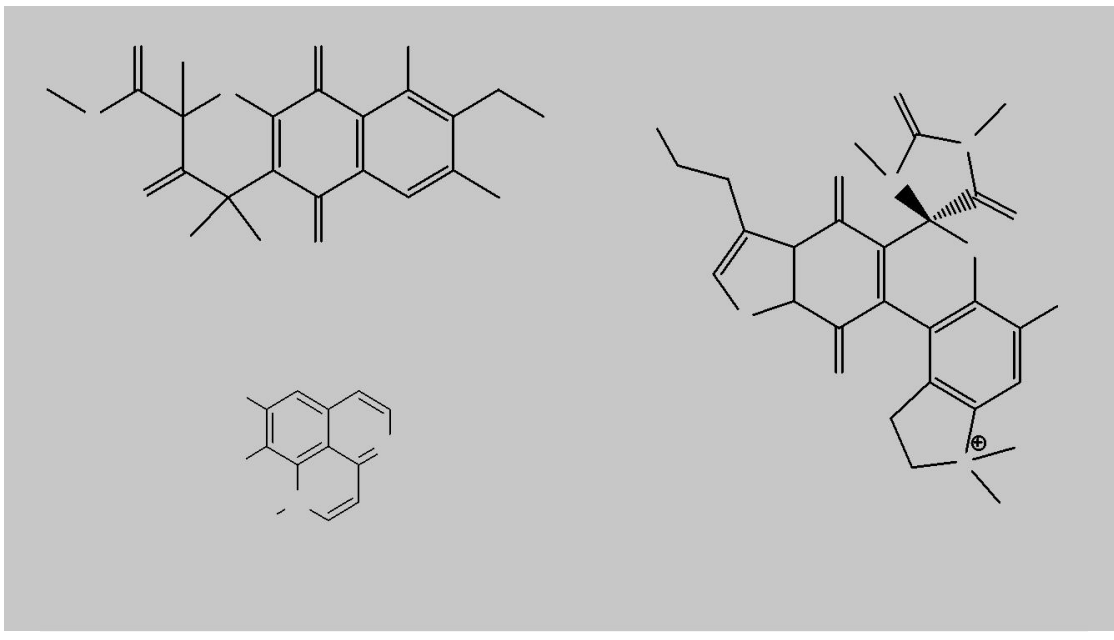

Gambar 3. Senyawa-senyawa penghambat IDO dari bahan alam laut. Annulin $B(K \mathrm{i} 0,12 \mu \mathrm{M}, 1)$ dari hydroid laut Garveia innulata, Exiguamine $\mathrm{A}(K \mathrm{i} 0,04 \mu \mathrm{M}, 2)$ dari spons laut Neopetrosia exigua dan Isoaaptamine dari spons laut Aaptos cf. suberitoides $\left(\mathrm{IC}_{50} 8,8 \mu \mathrm{M}, 3\right)$. 


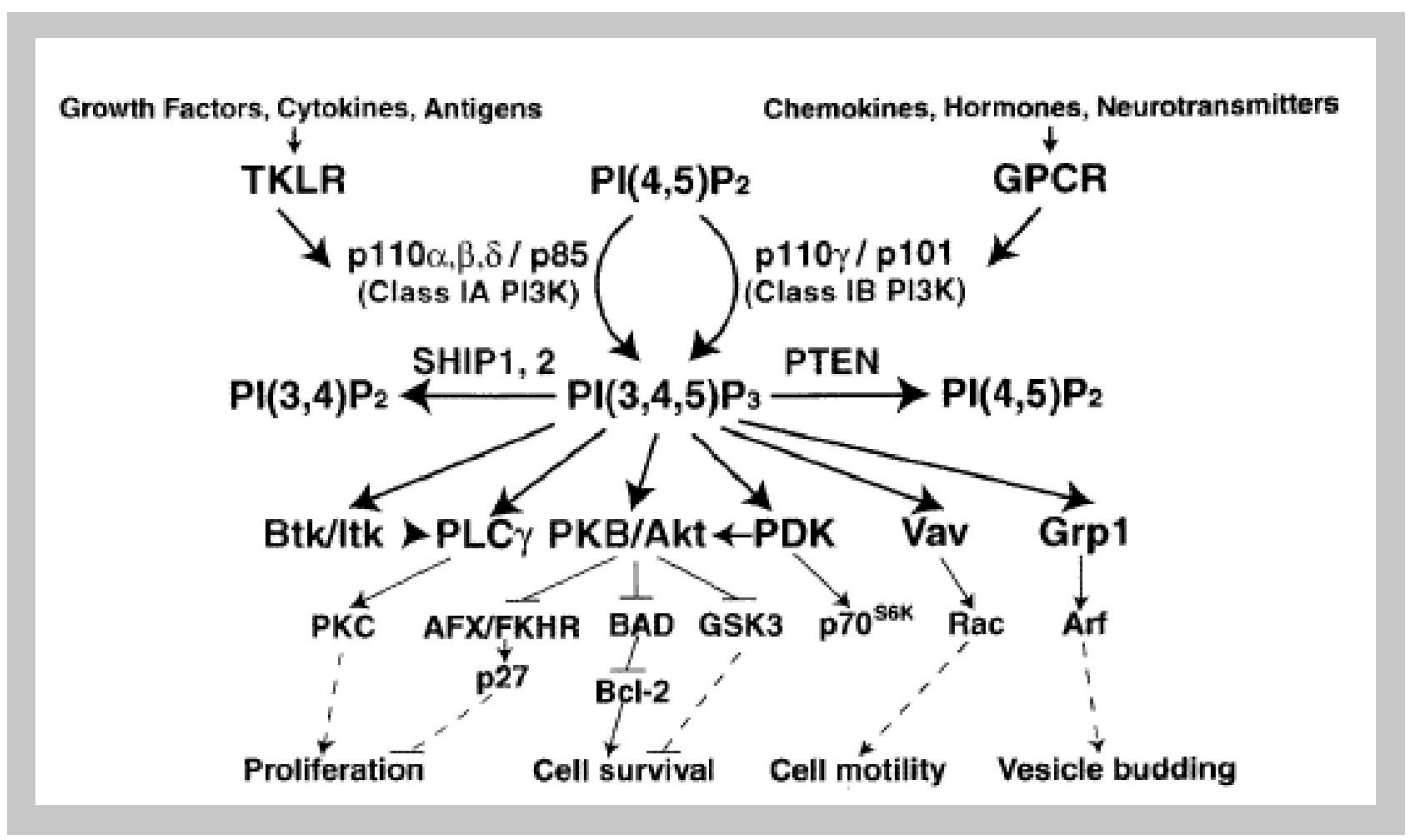

Gambar 4. Mekanisme biosintesis dan degradasi PI-3,4,5-P3 (Sasaki et al., 2002).

molekul $145 \mathrm{kDa}$ yang secara selektif menghidrolisis 5-fosfat dari inositol-1,3,4,5-tetraphosphate (I-1,3,4,5P4) dan phosphatidylinositol-3,4,5-triphosphate (PI3,4,5-P3) menjadi phosphatidylinositol-3,4biphosphate (PI-3,4-P2) secara in-vitro dan in-vivo. Protein ini sangat unik di antara 5-fosfatase lainnya karena merupakan satu-satunya enzim yang mempunyai domain src homology $2(\mathrm{SH} 2)$ dan oleh karena itu dikenal sebagai SH2 containing inositol-5phosphatase (SHIP) (Krystal et al., 1999; Liu et al., 1997). SHIP memiliki kemampuan yang sama dengan suatu gen suppressor tumor yaitu phosphatase and tensin homologue (PTEN) yang terdapat pada kebanyakan sel kanker dan berfungsi untuk menghidrolisis 3-fosfat dari PI-3,4,5-P3 dan menghambat jalur PI3K (Choi et al., 2002).

Selain SHIP, grup peneliti Kerr menemukan protein sejenis yaitu SSHIP yang tidak memiliki domain $\mathrm{SH} 2$ dan hanya diekspresikan di sel punca (stem cell) embrio dan darah. Grup peneliti Pessese juga melaporkan SHIP2 yang diisolasi dari sel-sel pembentuk darah. Kedua protein ini memiliki fungsi yang sama dengan SHIP (Sly et al., 2003).

Kemampuan SHIP untuk mendekomposisi PI3,4,5-P3 menyebabkan protein ini dapat membatasi jumlah degranulasi mast cell. Oleh karena itu, SHIP mempunyai potensi untuk meregulasi pertumbuhan sel kanker yang dipicu oleh PI3K. SHIP juga diketahui sangat spesifik terhadap sel-sel pembentuk darah sehingga pengaktifan SHIP dapat berguna tidak hanya untuk penyembuhan dan pengobatan kanker, akan tetapi juga pengobatan penyakit atopis (penyakit alergi menurun) seperti asma (Krystal et al., 1999).

Jalur PI3K dibagi dalam 2 kelas dimana faktor ekstra-selular dapat mengikat tipe-tipe reseptor yang berbeda pada membran plasma. PI3K kelas IA diaktifkan secara tidak langsung oleh TKLR (tyrosine kinase-linked receptor). Sedangkan PI3K kelas IB diaktifkan oleh GPCR (G-protein-coupled-receptor). Produk utama dari aktivasi $\mathrm{PI} 3 \mathrm{~K}$ ini adalah $\mathrm{PI}-3,4,5-$ P3 yang dapat dihidrolisis menjadi bentuk bifosfat oleh PTEN dan SHIP. PI-3,4,5-P3 inilah yang bertanggungjawab terhadap beberapa regulasi fungsi sel kanker (Sasaki et al., 2002).

Berbeda dengan IDO, senyawa-senyawa aktivator SHIP belum banyak dilaporkan. Pada tahun 2005, Yang mendemonstrasikan bahwa senyawa pelorol (4), suatu senyawa meroterpenoid dari spons laut Dactylospongia elegans, mengaktifkan SHIP secara in vitro. Yang kemudian melakukan sintesis beberapa senyawa analog pelorol dan menemukan bahwa penggantian gugus metil ester dengan gugus metil serta keberadaan gugus fenol meningkatkan aktivitas senyawa turunan tersebut (5) (Dewi, 2009).

Penelitian lebih lanjut menunjukkan bahwa keberadaan gugus katekol pada senyawa analog pelorol dapat mengikat metal atau membentuk ortokuinon sehingga dapat menghambat interaksi ikatan spesifik dengan protein. Oleh karena itu, senyawa turunan pelorol generasi kedua dikembangkan dan dilabeli dengan nama MN100 (6) yang saat ini dikenal sebagai aktivator SHIP paling aktif. Dewi (2009) juga menambahkan bahwa 


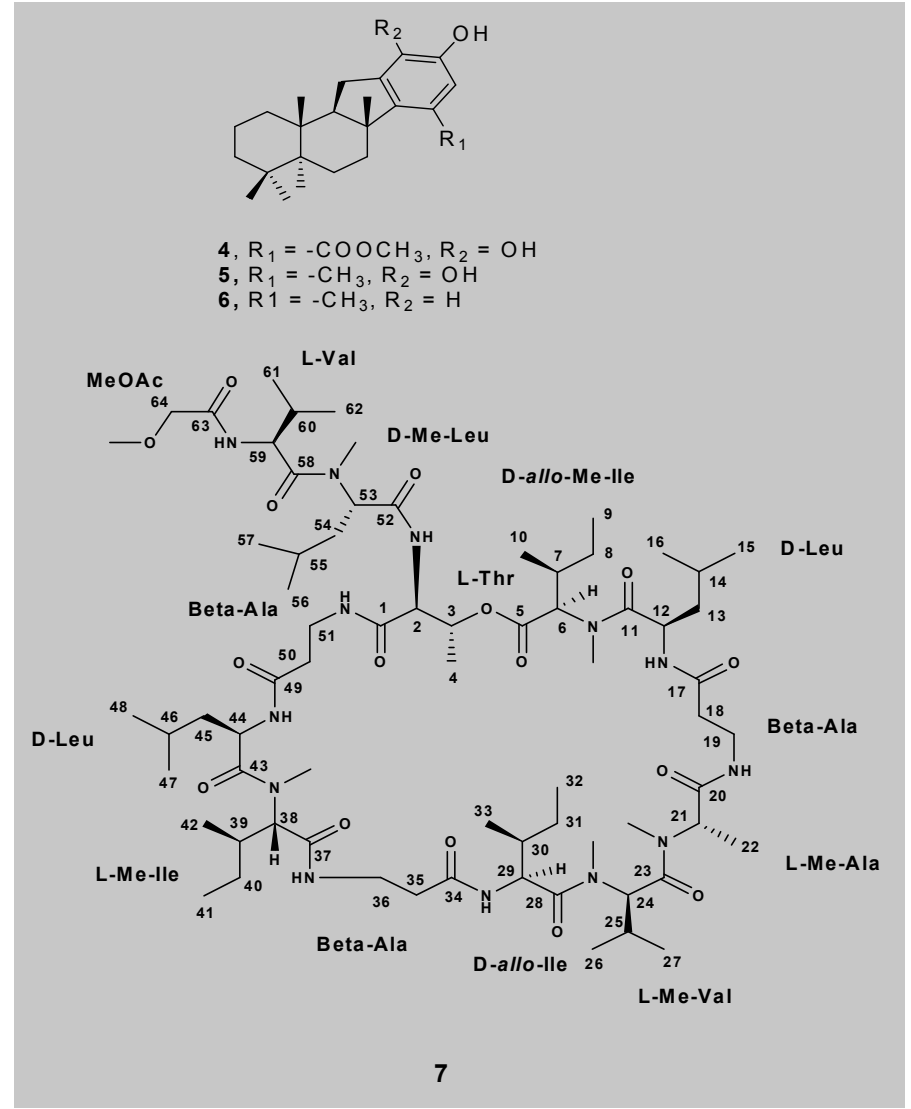

Gambar 5. Senyawa-senyawa aktivator SHIP dari bahan alam laut. Pelorol (4) dan senyawa turunannya (5). MN100 (6) adalah turunan pelorol generasi kedua yang diketahui sebagai aktivator SHIP paling aktif. Theonellapeoptida Id (7), peptida pertama yang dilaporkan sebagai aktivator SHIP, diisolasi dari spons laut Indonesia (Dewi, 2009).

theonellapeptolide Id (7), suatu peptolida langka yang mengandung asam amino $\mathrm{N}$-metil, $D$-asam amino dan $\beta$-asam amino dengan jumah yang tinggi dari spons laut mampu meningkatkan aktivitas SHIP sebesar $25 \%$ pada konsentrasi $124 \mu \mathrm{M}$.

\section{PENUTUP}

Pendekatan imunoterapi pada pengobatan kanker adalah suatu terobosan baru dalam dunia kesehatan yang diharapkan dapat menjawab permasalahan yang ditimbulkan oleh terapi kanker konvensional. Pengembangan terapi ini diharapkan tidak hanya sekedar mengeliminasi kanker tetapi juga meningkatkan kualitas hidup penderitanya. Sumber daya biota laut tropis Indonesia yang melimpah menjanjikan prospek yang sangat besar untuk penemuan senyawa-senyawa bioaktif baru yang berpotensi untuk dikembangkan sebagai agen imunoterapi kanker. Didukung dengan penemuanpenemuan target molekuler baru, akan semakin banyak peluang yang dapat disumbangkan oleh bahan alam laut kita untuk pengembangan obat kanker di masa mendatang.

\section{DAFTAR PUSTAKA}

American Cancer Society. 2008. Cancer Facts and Figures Atlanta: American Cancer Society, p. 1-68.

Blattman, J.N. and Philip, D.G. 2004. Cancer immunotherapy: a treatment for the masses. Science 305, p. 200-205.

Boik, J. 1995. Cancer and Natural Medicine, 5 pp.

Choi, Y., Zhang, J., Murga, C., Yu, H., Koller, E., Monia, B. P., Gutkind, J.S., and Li, W.Q. 2002. PTEN, but not SHIP and SHIP 2, suppresses the PI3K/Akt pathway and induces growth inhibition and apoptosis of myeloma cells. Oncogene, 21 (34), 5289-5300.

Dewi, A.S. 2009. Biologically Active Secondary Metabolites From Tropical Marine Organisms. Thesis. The University of British Columbia, Canada. p. 56-57, 78.

Dewi, A.S., Tay, W., Mauk, G. A., Andersen, R.J., and Small molecule inhibitors of Indoleamine-2,3-dioxygenase (IDO) from Aaptos cf. suberitoides. Jurnal Penelitian Perikanan Indonesia. Submitted. 
Jemal, A., Siegel, R., Ward, E., Murray, T., Xu, J., and Thun, M. J. 2007. Cancer Statistics, 2007. A Cancer Journal for Clinicians. 57. 43-66.

Katz, J.B., Muller, A.J., and Prendergast, G.C. 2008. Indoleamine 2,3-dioxygenase in T-cell tolerance and tumoral immune escape. Immunological Reviews. 222. 206-221.

Krystal, G., Damen, J.E., Helgason C.D., Huber, M., Hughes, M.R., Kalesnikoff, J., Lam, V., Rosten, P., Ware, M.D., Yew, S., Humphrey, R.K., and SHIPs ahoy. 1999. The International Journal of Biochemistry and Cell Biology. 31. 1007-1010.

Mellor, A. 2005. Indoleamine 2,3 dioxygenase and regulation of $\mathrm{T}$ cell immunity. Biochemical and Biophysical Research Communications. 338 (1). 2024.

Muller, A.J. and Prendergast, G.C. 2005. Marrying immunotherapy: why say IDO? Cancer Research. 65 (18). 8065-8068.

Munn, D.H. 2006. Indoleamine 2,3-dioxygenase, tumorinduced tolerance and counter-regulation. Current Opinion in Immunology. 18 (2), 220-225.

Parish, C.R. 2003. Cancer immunotherapy: The Past, The Present and The Future. p. 106-113.

Pervaiz, S. 2002. Anti-cancer drugs of today and tomorrow: Are we close to making the turn from treating to curing cancer? Current Pharmaceutical Design. 8 (19). 1723-1734.

Prasad, N.K., Tandon, M., Badve, S., Snyder, P.W., and Nakshatri, H. 2008. Phosphoinositol phosphatase SHIP2 promotes cancer development and metastasis coupled with alterations in EGF receptor turnover. Carcinogenesis. 29 (1). 25-34.

Prendergast, G.C. 2008. Immune escape as a fundamental trait of cancer: focus on IDO. Oncogene. 27 (28). 3889-3900.

Sasaki, T., Suzuki, A., Sasaki, J., and Penninger, J.M. 2002. Phosphoinositide-3-kinase in immunity: lessons from knockout mice. Journal of Biochemistry. 495501.

Schuster, M., Nechansky, A., Loibner, H., and Kircheis, R. 2006. Cancer immunoterapy. Biotechnology Journal. 1. p. $138-147$.

Sly, L.M., Rauh, M.J., Kalesnikoff, J., Buchse, T., and Krystal, G. 2003. SHIP, SHIP2, and PTEN activities are regulated in vivo by modulation of their protein levels: SHIP is up-regulated in macrophages and mast cells by lipopolysaccharide. Experimental Hematology. 31 (12).1170-1181.

Zamanakou, M., Germenis, A. E., and Karanikas, V. 2007. Tumor immune escape mediated by indoleamine 2,3-dioxygenase. Immunology Letters. 111 (2). 69-75. 